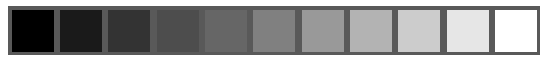

Imaginário - usp, 2007, vol. 13, n 14, 461-482

\title{
O interjogo consciente-inconsciente
}

\author{
Ione Aparecida Xavier* \\ O interjogo consciente-inconsciente, aplicado no \\ conto "O Enfermeiro", de Machado de Assis
}

Introdução

Freud, pioneiro também em analisar à luz da Psicanálise produções artísticas e literárias, em Delírios e Sonhos na Gradiva de Jensen (1907), ao discorrer sobre a obra de Wilhelm Jensen, inspirou-nos na análise da obra literária de Machado de Assis, "O Enfermeiro".

Freud (1907), tentando responder a uma inquietação de Jung sobre a interpretação dos sonhos (em obras literárias) focaliza, na obra, os delírios e sonhos do protagonista arqueólogo Norbert Hanold, que, ao comprar uma estatueta - Gradiva - de Pompéia (Roma de $79 \mathrm{DC}$ ), fica fascinado por sua maneira de andar (pouco típica nas mulheres de sua época). Decepcionado com a realidade, viaja para Pompéia em busca de Gradiva e a vê não só em seus sonhos, mas pelas ruas da cidade. Trata-se de uma jovem chamada Zoe, a qual ele acreditava piamente ter sido a mesma jovem que havia vivido em Pompéia e que lhe faz, do ponto de vista de Freud (1907) associações e interpretações do que percebe como um caso clínico bemsucedido por parte da personagem Zoe, embora esta não tenha conhecimento disso. Finalmente, Freud (1907) deixa ao leitor o
* Doutora em Psicologia Clínica pela PUC de Campinas, Coordenadora e Supervisora do Centro de Psicologia Aplicada da UNIP - Sorocaba, Psicoterapeuta Familiar.

XAVIER, I. A. O interjogo consciente-inconsciente. UNIP, Sorocaba, 2006. 


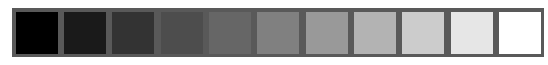

Xavier, I. A. O interjogo consciente-inconsciente

direito de estar satisfeito ou não com tais interpretações. O autor não estava interessado exatamente na maneira pela qual os escritores faziam uso de seus sonhos, mas contribuiu ressaltando de forma ímpar com a natureza da criação literária, embora não considerasse esse seu trabalho como não sendo muito relevante. O que fato chama a atenção de Freud (1907) é que o autor faz sonhar os personagens, retratando o estado de espírito de seus heróis por meio de seus sonhos. Assim, Freud (1907) acredita que Wilhelm Jensen, ao realizar tal obra, tenha se reportado ao inconsciente, atento às suas manifestações, expressando-o através da arte. $O$ que parece tornar a obra universal é a liberação dessse inconsciente sem medo de reprimi-lo com qualquer crítica consciente.

Freud (1907) aponta para a importância da compreensão dos processos da vida mental referindo-se a uma divisão psíquica em consciente e inconsciente. A trama vivida pelo casal Norbert Hanold e Zoe, sobretudo da primeira personagem, fixado por um amor dirigido a uma estatueta da Gradiva (cuja encarnação se deu em Zoe seu antigo amor de infância, a qual compartilha de seu delírio), nos faz crer que um estado de consciência pode ser transitório, ou seja, um elemento psíquico (por exemplo, a idéia) pode não ser considerado consciente por muito tempo. O que parece determinar esse estado de transição é a maneira (recurso utilizado pelo aparelho psíquico, seja ele quantitativo ou econômico) como ocorre no processo dinâmico mental. No caso das personagens em questão, o fato de Zoe compartilhar do delírio de Harold, fingindo-se ser a amada de mármore Gradiva, acaba libertando-o de suas repressões e devolvendo-Ihe sentimentos, agora integrados, que anteriormente o fizeram sofrer.

Freud (1923) ainda afirma que "a razão pela qual tais idéias não podem tornar-se conscientes é que uma certa força se lhes opõe" (p. 26). Antes de se tornar consciente, essa idéia encontrava-se censurada e percebida no processo analítico pela resistência.

Grosso modo, pode-se dizer que o que é latente pode ser capaz de tornar-se consciente enquanto o que é reprimido não é capaz de tornar-se consciente (a menos que se recorra um investimento próprio, como a análise). 
Portanto, acreditamos que a contribuição da análise de Freud sobre a Gradiva possa nos ajudar a compreender a obra Machadiana em sua universalidade, partindo do mesmo pressuposto de que a obra criativa libera o inconsciente sem medo de reprimi-lo com qualquer crítica consciente. O fato é que a criatividade do autor contribui para os pensamentos de Freud (1907) ao dizer "fiquei bastante surpreso ao verificar que o autor de Gradiva publicado em 1903 baseara sua criação justamente naquilo que eu próprio acreditava ter acabado de descobrir a partir das fontes de minha experiência médica. Como pudera o autor alcançar conhecimentos idênticos aos do médico ou pelo menos comportar-se como se os possuísse?" (p. 60).

Fazendo assim valer as possibilidades metodológicas da Psicanálise em uma obra literária, analisaremos um conto - "O Enfermeiro" - de Machado de Assis, levando em conta o que diz Rezende (1987): "o aspecto simbólico de uma obra por si só exige interpretação, embora este não esgote toda a sua riqueza". Aspecto esse que nos reporta aos determinantes subjacentes a obra, ao considerarmos os diferentes leitores e diferentes momentos e motivos vividos pelo leitor e pelo autor para a sua criação, somados aos aspectos culturais.

Herrmann (1993) fala sobre o objeto de estudo da Psicanálise (o inconsciente) e busca respostas para a questão das condições de seu exercício dentro ou fora do "setting". Discorre sobre a sua utilização nas produções humanas, apontando para o alcance do inconsciente e conseqüentemente para a amplitude do método psicanalítico que pode ser dirigido, por exemplo, a uma obra literária e seu leitor, como pudemos constatar no caso de Freud (1907).

Herrmann (1993) acredita que, ao aplicar o método psicanalítico, deve-se ter em conta um conjunto de relações humanas, entendendo "relação" não apenas no seu aspecto interpessoal mas, por exemplo, na relação existente entre uma obra literária e seu leitor, entre uma estrutura social e seus participantes etc. "Aplicar o método psicanalítico é fazer brotar, do estudo de algumas relações humanas, as estruturas profundas que a determinam" (p. 134). Ressalta a importância do "inconsciente relativo", que, de acordo com o autor, consiste na possibilidade de transformar o método 


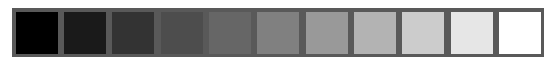

Xavier, I. A. O interjogo consciente-inconsciente

psicanalítico em pesquisa. Fazer brotar o determinante inconsciente da estrutura profunda geradora do sentido humano pode elucidar melhor a profundidade dessa estrutura. Se o inconsciente é determinado pela interpretação terapêutica é preciso considerar também que cada relação humana comporta múltiplos níveis de determinação. Para cada nível, evoca-se uma estrutura determinante de diferentes profundidades; o que Herrmann (1993) define como o "inconsciente relativo" é determinado pelo choque de diferentes representações em um nível dado (p. 137).

Herrmann (1993), ao explicar sobre o "inconsciente relativo", relata sua experiência no ensaio "Andaimes do Real II: o cotidiano", em que apresenta quatro contos de diversos autores, parafraseando o conto famoso de Machado de Assis. Ressalta que um autor havia escrito sobre o ângulo do rapaz, outro sobre o ângulo da amante, da empregada da casa, de personagens de outros textos de Machado de Assis e assim por diante. Ao se questionar sobre o que esses diferentes contos têm de inconsciente, ele nos responde que 0 inconsciente dessas histórias não é o inconsciente dos autores, sequer o inconsciente de Machado de Assis, mas, provavelmente, para algum pesquisador num futuro longínquo, esses contos poderão ter algum sentido ou propriedades antes inexplicáveis. Isso seria para o autor o "inconsciente relativo".

A partir dessa perspectiva de Herrmann (1993), a proposta é a de seguir transferencialmente, dando sentido ao objeto doravante estudado (descortinando a partir de uma obra literária O Enfermeiro de Machado de Assis), que sem dúvida abre um caminho desafiador no intento de convertermos método psicanalítico em pesquisa.

Este estudo rastreia o que Herrmann (1993) chama de "inconsciente relativo" em um conto de Machado de Assis. Acreditamos que, na fruição de uma obra de arte, um autor entra em um tipo peculiar de relação com o leitor, estabelecendo, com a sua participação, um campo interpsíquico, no qual certos aspectos são manipulados por ele de modo a determinar as características de campo, direcionando a leitura para determinado objetivo artístico. 


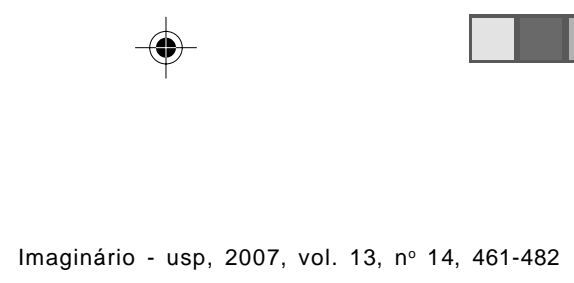

Tal rastreamento se distingue da análise literária, em que são focalizadas as intenções e técnicas do autor, assim como as linhas de significações que compõem a obra e a sua aura artística emocional. Também não se trata de uma análise do inconsciente ao autor, a quem não temos acesso. A intenção é revelar o aspecto do homossexualismo vivido pelas personagens, cuja problemática psicológica determina os acontecimentos do texto, e sua matriz emocional, assim como Freud revelou o complexo subjacente ao Édipo Rei, de Sófocles.

\section{O interjogo consciente-inconsciente aplicado no conto}

Vamos iniciar a interpretação do conto com a investigação do interjogo que ocorre no aparelho psíquico entre Cs e Ics, em que o acesso de um material dessa última instância deve passar por uma censura para chegar à primeira. Essa censura pode, muitas vezes, dificultar a compreensão do significado e do seu alcance. É o que percebemos no início da narrativa, quando Machado de Assis traz uma questão, ou seja, uma dúvida, quanto à importância do que seria relatado pela personagem do enfermeiro. Existe algo que se considera importante para ser revelado (ou trazido à consciência), porém impõe a condição de que esse material seja revelado apenas após a sua morte, denotando uma ponta de dúvida sobre se quer ou não entrar em contato com ele, apresentando esse material como fato real, ao falar de sua história. Portanto, prestes a fazer uma revelação que pode ter inicialmente um valor de culpa ou vergonha.

A impessoalidade com que resolve relatar o fato ocorrido vem ao encontro da dificuldade em que se depara, pois existe um desejo de revelar sua história, e, em contraposição, outro desejo, de que esta seja divulgada apenas depois de seu óbito. Podemos supor que só fará essa revelação na certeza de que não entrará em contato com as conseqüências dela, já que está com os seus dias contados, o que nos oferece uma primeira indicação de uma resistência em assumir culpas. 


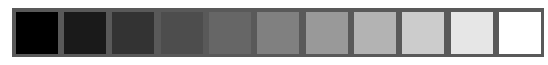

Xavier, I. A. O interjogo consciente-inconsciente

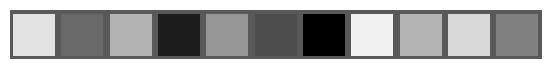

O fato de estar prestes a morrer permitiu que nossa personagem (o enfermeiro) se revelasse, falando de sua vida e, porque não dizer, de seus desejos reprimidos. Essa transparência retrata o seu funcionamento mental, o que faz com que nós leitores nos deparemos com o que pode estar sendo de difícil compreensão. O que tem a dizer será mesmo tão importante? Se for, a ponto de dar origem a um livro, por que necessitaria de perdão? A questão que se estabelece é que essa liberação psíquica pode associar-se ao fato de não ter mais o que perder (já que está no fim da vida), e qualquer tipo de revelação nesse momento pode já não ter o mesmo peso que antes. Inicialmente, poderíamos dizer que para nós leitores entrar em contato com a liberação do autor facilitaria nossa própria liberação enquanto funcionamento mental.

Denota preocupação com sua auto-imagem ao pedir ao ouvinte que não o julgue e que o perdoe. E, nesse momento, o autor tenta seduzir o leitor a manifestar sua curiosidade independentemente do que venha a ser a revelação. Aqui ele dá ao leitor a possibilidade de adentrar nas diferentes facetas desse interjogo, sem medo.

Não sabemos muito do passado da personagem, a não ser o que ela se propõe a nos dizer. Esse fator pode contribuir ou não para a identificação do leitor. Ao selecionar alguns fatos em sua narrativa, vamos dando-nos conta de que o enfermeiro elege aspectos que nos fazem inferir sobre sua maneira de agir e pensar que podem nos ajudar a descobrir de que maneira se manifesta esse interjogo psíquico em um nível inconsciente. Fala de sua ligação com a Igreja e com a fé. Chama a nossa atenção para o mês de agosto, quando tudo parece ter se iniciado (e não podemos nos esquecer de que, na concepção da Igreja, o mês de agosto é intitulado o mês das vocações). Em contrapartida, no vulgo popular, o mês de agosto é tido como o mês do agouro, do azar e da loucura. Nesse momento, percebemos sua ligação psicodinâmica com a Igreja, que parece ser a mais intensa, revelando seus aspectos depressivo, impotente e masoquista ao se vincular a um amigo de colégio que gentilmente Ihe dá casa, cama e mesa em troca de um trabalho de cópia de estudos de Teologia. 
Continuando nossa reflexão sobre o mês de agosto, parece ser nesse momento que ele se sente chamado para uma determinada missão para a qual não pode se negar. Mas o autor nos coloca uma dúvida sobre esta sua bondade interior, como veremos a seguir. $O$ padre amigo recebe uma carta de um vigário do interior, requisitando pessoa entendida, discreta e paciente para servir de enfermeiro a um coronel em troca de um bom ordenado. Como leitores, resta-nos uma dúvida inicial sobre a bondade e vocação de nossa personagem. Estaria se prestando a trabalhos serviçais por interesse ou não? Estaria disposta a aceitar tal tarefa missionária (já que fora um pedido de um outro vigário) pela mesma bondade e vocação ou apenas pelo bom ordenado oferecido pelo coronel?

Até aqui, o autor nos coloca algumas questões, de realidade, sobre a verdadeira ocupação da personagem. Não era padre, embora estivesse ligado à Igreja (de forma dependente); não era enfermeiro, mas aceita a incumbência de tal tarefa (por bondade ou por interesse). $O$ autor coloca ao leitor a idéia de que para exercer a referida profissão era preciso ter vocação. Podemos inferir que a escolha dessa função talvez lhe traga alguns benefícios, em um nível inconsciente, vindo ao encontro de desejos reprimidos, possibilitando-Ihes viver seus aspectos homossexuais, sádico e masoquistas.

O suposto enfermeiro aceita a missão com as duas mãos. Mãos que deixam de servir a Igreja (um pai bondoso) para servir a uma autoridade (um pai castrador). Aqui podemos perceber uma manifestação psíquica superegóica direcionada a pessoas com autoridade. "Entregar-se com as duas mãos" pode querer dizer entregar-se totalmente, de corpo e alma, de forma submissa, buscando resolver seus conflitos do passado. Nesse trecho do relato, trata-se de nos apresentar as pessoas com as quais ele tem vínculo afetivo, ou seja, o padre amigo e o irmão de quem vai se despedir ao aceitar o novo trabalho. Coincidentemente ou não, todos os vínculos são com pessoas do sexo masculino, denotando sua tendência homossexual.

Relata o desafio que tinha pela frente (com a possibilidade de reviver antigos conflitos), desafio esse direcionado ao coletivo, ao falar dos 


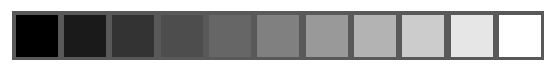

Xavier, I. A. O interjogo consciente-inconsciente

moradores da pequena vila do interior, que maldiziam o coronel. Nesse momento, o autor deixa claro que a figura do coronel é misteriosa e austera, o que possibilitaria uma vivência transferencial entre as personagens, comum do universo adulto.

Contudo, a nossa personagem mostra com orgulho sua força psíquica e seus aspectos onipotentes por não se preocupar em ter de ultrapassar as fronteiras psíquicas (do que é sadio ou doentio -e já que estará diante do pai castrador) e uma determinação inabalável ao responder aos moradores que não tinha medo de pessoas sãs e menos ainda de doentes. Essa determinação é confirmada pela pessoa do vigário, que lhe recomenda atitudes de mansidão e caridade, com as quais segue o seu destino. Poderíamos nos perguntar, de onde vem tal força para enfrentar tal autoridade de igual para igual, contrariando um temor coletivo da pequena vila? Quem seria este forasteiro e de que arma disporia para enfrentar o coronel? Parece que a mesma ousadia que o torna forte o suficiente para enfrentar um homem temido por toda uma cidade o coloca numa postura passiva e dependente. Aqui, sua ação determinante, ousada, revela sua defesa, utilizada na tentativa de esconder os conteúdos latentes.

Do que temos como informação até o momento, ele tem um irmão que mora na Corte, do qual aparentemente se distancia. Poderíamos deduzir que há uma tendência a se enclausurar (evidenciando seu aspecto masoquista) como uma espécie de sentença predestinada em sua vida. A internalização da figura paterna castradora possibilitou ao superego da personagem relacionar suas vivências passadas ou pressões psíquicas internas em suas inter-relações diárias. Ora se vê preso a um padre, fazendo cópias que o enfadavam, ora se vê preso a um doente insuportável. Evidencia-se aqui um complexo de culpa que podemos associar à figura masculina, como foi dito acima, já que até o momento não citou nenhuma figura do sexo oposto. Poderíamos inferir sobre a sua imaturidade psíquica quando voltada para as questões de vínculo afetivo.

No momento em que se encontra com o coronel, expressa suas primeiras impressões. Ao compará-lo com um animal, podemos 


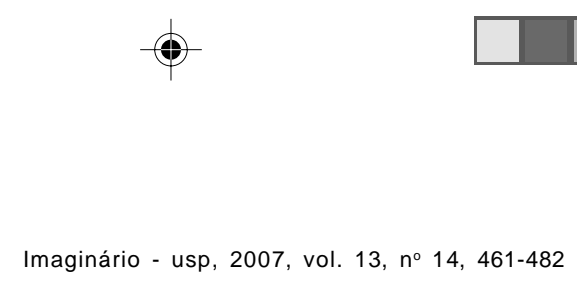

dizer que é nesse nível mais primitivo que se estabelecem impressões de ambos os lados. Entende o silêncio do coronel ao vê-lo (talvez um silêncio cheio de mensagens subentendidas) e volta à sua percepção inicial, comparando-o com um animal com feições ambíguas, denotando certa familiaridade de alguma característica positiva nesse primeiro encontro.

Percebemos como leitores um momento de sedução neste encontro, a partir das respostas que nossa personagem dá ao coronel, respostas que the soam bem aos ouvidos ao responder-lhe, por exemplo, que não era gatuno, e em seguida permitindo ao coronel trocar-lhe o nome. Neste momento, relata que deixa de ser Valongo para ser Procópio, como desejava o coronel. Tipicamente como ocorre em um casamento, quando a mulher deixa o seu nome de solteira e passa a usar o nome do marido. O enfermeiro assume sua identidade inconsciente despertada pelo coronel (castrador) numa posição passiva. Aqui, deparamo-nos com uma mistura do princípio do prazer a serviço do superego. O interjogo de projeções e identificações evidencia-se nesse momento.

A personagem do enfermeiro parece seduzir e ser seduzida, concretizando, porque não dizer, um encontro de aspectos reprimidos sexuais que, graciosamente, narra como tendo sido uma lua-de-mel de sete dias entre os dois. Até aqui o autor parece querer conduzir o leitor a afeiçoar-se à personagem, pela sua façanha, por ser 0 único, dentre tantos enfermeiros, a conquistar o coronel temido por toda cidade. Como toda lua-de-mel tem um fim, narra sobre a vida de cão que passou a levar (a partir do oitavo dia) acolhendo injúrias, o que aprendeu a fazer com resignação e conformidade, pois assim correspondia à corte do coronel. Evidencia-se aqui um lado passivo masoquista dentro deste contexto de lua-de-mel que evoca seu aspecto feminino ao casar-se com o coronel sadicamente viril.

Constatar, a partir da realidade da doença do coronel, qual seria seu papel por um momento fez que nossa personagem desejasse abandoná-lo. O autor deixa claro para o leitor que ela só o faria se houvesse um motivo, ou seja, na ocasião certa. Nas percepções egóicas, a ocasião certa é aquela para a qual há uma explicação 


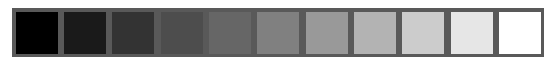

Xavier, I. A. O interjogo consciente-inconsciente

plausível. No interjogo psíquico podemos dizer que essa explicação é dada de um lado pelos maus tratos, de outro pelos sentimentos de culpa associados a impulsos reprimidos, indicando homossexualismo. Enquanto as injúrias do coronel se davam apenas em nível verbal, a personagem nos dá indícios de que se sujeitaria a todas elas, tentando ignorá-las. Basta que essas injúrias se tornem concretas em nível físico para que se posicione diante do coronel. Depois de ter sofrido três golpes de bengala, resolve fazer as malas e abandoná-lo. O coronel, por sua vez, ao perceber a determinação do enfermeiro em deixá-lo, resolve ter com ele, no quarto, pedindoIhe que fique. $O$ coronel vai ao quarto do enfermeiro, à noite, invadindo sua privacidade, e lá trata de fazer um pacto de morte com o mesmo. Poderíamos dizer que, nesse momento, o autor se faz valer do aspecto simbólico para a verdadeira expressão da sua obra. Concretizar a relação em "bengaladas" (objeto fálico) pode querer significar concretizar essa relação em um nível sexual. Invadir sua privacidade pode também querer dizer praticar relação sexual violenta e intrusiva com ela.

O coronel, ao fazer o pacto, diz que "não pode viver muito tempo", dando uma dupla mensagem para nós leitores que podemos entender suas palavras como sendo um pedido de ajuda, para que o enfermeiro lhe antecipe a morte, ou como sendo pura expressão onipotente do coronel que decide ele mesmo quanto pode ou não viver. Sentencia o pacto dizendo-Ihe que não o dispensaria nunca e que, por determinação dele, coronel, o enfermeiro deveria acompanhá-lo até que a morte os separasse, acentuando o ritual do casamento. $O$ ocorrido se passa à noite e mais uma vez o interjogo psíquico denota dúvidas sobre a história da violência ser verdadeira ou falsa. O que podemos inferir é que essa agressividade, falsa ou não, seria um bom motivo racional para justificar a herança da "viúva" como dívida de gratidão, pouco condizente com a imagem que ela passa para o coronel. Esse relato, somado aos demais, seria uma tentativa de encobrir o sexual com a agressividade.

Fazem as pazes, mas logo em seguida relata seu sofrimento ao ouvir novas injúrias do coronel, que foram retomadas de maneira pior que antes, o que poderíamos subentender como sendo agressões ou 


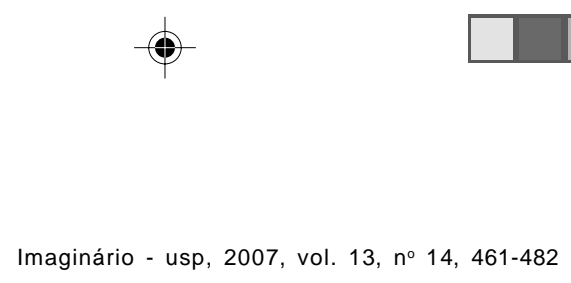

relações sexuais mais íntimas. Podemos dizer que a relação esquizoparanóide se estabelece de vez, com as projeções e identificações de ambos. O enfermeiro fala do sentimento de solidão, sendo o único a estar ali para ouvi-lo e resolve sair, mas novamente persuadido pelo vigário, muda de idéia. Poderíamos desconfiar que muda de idéia muito facilmente, a despeito de toda a sua demonstrada força mental. Já não haveria aqui em operação um álibi para a permanência? Fica porque o vigário pediu e não por causa do relacionamento.

A idéia de abandonar o coronel pairava constantemente sobre o seu pensamento. Refere-se à sua relação com ele como melindrosa e, talvez por se sentir muito exposto, quisesse voltar à Corte. Ao tocar no aspecto da sua solidão, isolamento e reclusão, aponta para 0 momento de introspecção em que vive. Há um forte desejo de voltar à Corte, nem que para isso tenha de brigar com o vigário. Logo em seguida, expressa um outro desejo de querer gastar na Corte todo o dinheiro que vinha guardando integralmente de seus ordenados. Talvez o dinheiro já fosse suficiente para desobrigá-lo de aturar uma situação infamante.

Ainda não bastasse o que já havia vivido, aparenta estar munido de esperança de um motivo real para poder se separar do coronel e leva a sério o "até que a morte os separe"; motivo esse, agora, explicitamente ligado à morte, uma vez que a saúde dele está cada vez pior, dando ao leitor pista do seu desejo de morte. Se não o fosse, por que não podia simplesmente ir embora, como sempre fizeram todos? Vamos nos deparar com esse desejo quando relata que o coronel deixou preparado seu testamento. Ele o fizera sozinho, sem seu conhecimento. Aqui nos deparamos com os verdadeiros sentimentos de uma viúva declarante de seus direitos. Acometido de seus desejos obscuros, o enfermeiro deixa escapar seus planos a respeito do coronel, ao expressar que trazia dentro de si um fermento de ódio e aversão. Essa seria uma "explicação plausível" para a sua inacreditável permanência.

O autor traz novamente o mês de agosto para que a nossa personagem dê um destino à sua vida "missionária". É nesse mês que ela resolve sair definitivamente e mais uma vez é persuadida a ficar, 


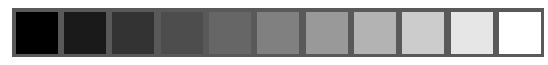

Xavier, I. A. O interjogo consciente-inconsciente

desta vez não só pelo vigário, mas também pelo médico, por mais um mês, até que lhe arrumassem um substituto.

Podemos nos perguntar como leitores curiosos por que o vigário insiste tanto para que o enfermeiro fique e por que ele sempre acaba cedendo aos pedidos do vigário? Estaria cada vez mais crente no seu poder de sedução ou estaria apenas sendo influenciado pelo que lhe pedia o vigário?

Ainda neste mês, o enfermeiro narra o que tanto vinha dizendo que aconteceria, só que surpreendendo a todos nós leitores. Como um desencadeador para a sua missão vocacional ou papel sacramentado, surge o coronel, explodindo com ele ao atirar-lhe um prato de mingau, provocando-o e ameaçando-o de morte e chamando-o de ladrão.

Parece que estamos diante de uma expectativa criada pelo autor que relata mais uma vez de maneira simbólica uma briga violenta e cheia de injúrias, terminando como todas as outras, neste caso, apaziguada pelo cansaço e sono (sugerindo mais uma relação sexual) que se abateu sobre o coronel e que fez com que a nossa personagem voltasse ao seu estado de resignação, ao lado do enfermo, como a esposa que repousa ao lado do marido, após ter cumprido seu papel.

Quando nós leitores pensávamos que o furacão do coronel estivesse adormecido, o autor surpreende-nos ao dar ao coronel um certo ar de delírio, arremessando a moringa contra o enfermeiro. Desta vez, 0 ataque fora certeiro provocando-Ihe ira, começando uma luta com o doente, com um fim trágico. Para selar a relação carnal deparamonos com mais um ímpeto instintivo sexual por parte do coronel que, ao ser correspondido, não resiste ao esforço físico e morre de prazer. Podemos nos atrever como leitores, uma vez que o autor nos coloca diante de uma situação duvidosa.

Não havia nenhuma testemunha. Por que acreditar no que a personagem fala? Nesse interjogo de dúvidas, a distorção é consciente, referida a fatos realmente acontecidos? Ou tudo não passa de conteúdos latentes reprimidos? Machadianamente falando: Capitu traiu ou não Bentinho? O casamento entre o coronel e o enfermeiro foi consumado ou ficou para sempre enrustido? 


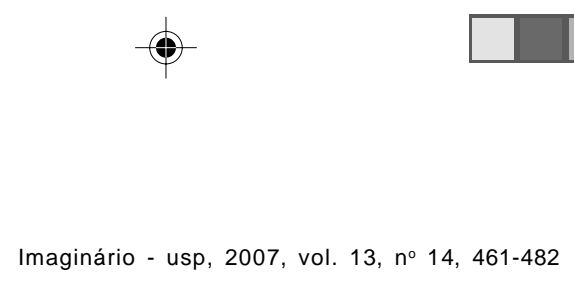

A partir desse momento, o autor tenta retratar como se daria uma situação em que determinado indivíduo se vê diante da morte (homicídio) que, até então, Ihe parecia apenas um desejo latente. Inicialmente parece negá-la, tentando evitar o que já havia constatado no momento em que o enforcou com as próprias mãos. É interessante que ninguém tenha ouvido ou percebido esse momento. Mais uma vez o autor coloca a confusão vivida pela psique em tal momento, quando o desejo inconsciente proibido, através de um ato irreversível e irreparável do Id, ultrapassa as barreiras profundas, atingindo a realidade, mas sendo ainda assim vivido como um delírio, um tormento que ecoava por meio de um superego alucinado que bradava aos seus ouvidos: "assassino". Aqui o autor nos relata em segundos o verdadeiro inferno em que se tornou a consciência da personagem, que daria tudo para voltar a sofrer as injúrias do coronel, denotando certo arrependimento, inclusive colocando como prova o fato de ter aceitado tal tarefa. Como parece duro demais assumir tal responsabilidade sozinha, por meio de distorções, trata logo de culpabilizar as pessoas que de certa forma eram responsáveis por ela estar ali, ou seja, primeiro o padre e em seguida o vigário e o médico que insistiram para que a personagem ficasse mais algum tempo, o que aos seus olhos fora o fato desencadeante para o terrível episódio do assassinato do coronel. Como leitores, possivelmente podemos nos ver envolvidos ao dividir tal culpa. Tal cumplicidade, no ato da leitura da obra talvez pudesse encobrir o desejo latente da personagem e por que não dizer, também nosso, ao acompanhar a história.

Quando o autor, talvez como nós, supostamente imbuído desse desejo, faz sua personagem atingir o momento de loucura e êxtase, ao "matar", faz-se valer em seguida dos sentimentos de arrependimento e culpa (persecutória) e termina por referir-se ao acontecido de maneira poética. Aqui ele tenta seduzir o leitor, deixando-nos mais confusos. Parece suspeito que o autor tenha em mente confundir o leitor. Por que motivos ele jogaria poeira em nossos olhos, para que desta maneira não possamos ver o que não pode ser visto? Parece-nos que a única explicação plausível se faz com a magnificência da obra de arte de todo artista que encanta seus 


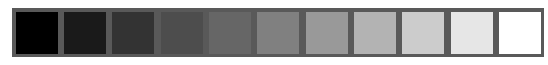

Xavier, I. A. O interjogo consciente-inconsciente

admiradores, que ao adentrarem na mesma, a eternalizam. A nossa personagem abre a janela e relata que a noite era tranqüila e que as estrelas fulguravam, o que a inspirou a encostar-se ali por um tempo e recapitular sua vida como quem naturalmente o faria em momentos de prazer e relaxamento. Com isso, vivencia seu mais íntimo momento de prazer, deixando de ser a esposa passiva e serviçal para poder desfrutar da herança que sem dúvida nenhuma pertenceria à viúva, como lhe era de direito, sentindo-se finalmente realizada.

Mas, não se deixa enganar pela bonança e logo trata de nos apresentar a tormenta em que vive, pensando em qual seria seu castigo por ter cometido tal crime. Essa idéia parece lhe tirar novamente 0 chão, a ponto de ter a nítida sensação de estar sendo espiada por três pessoas no terreno, o que a faz recuar do seu momento de recapitulação e se acalmar, dizendo para si mesma que não passara de uma alucinação.

Nesse momento o autor nos coloca uma dúvida, sobre isso ser ou não uma alucinação, o que podemos discutir mais adiante. Poderíamos discutir diante da possibilidade de vivenciar um desejo latente, que tudo o que parecia irreal ou inatingível passa a ser real e viceversa. Neste momento a realidade passa a ser a que a quer que seja, ao relatar que antes mesmo do alvorecer já havia curado sua contusão da face e que para se livrar dos vestígios de morte no pescoço do coronel - sinal de suas unhas - ela simplesmente abotoara a camisa na segurança de que ninguém repararia os vestígios do crime. Essa explicação dada pelo autor, mais uma vez, nos parece fácil demais para ser verdade. Vestígios de contusão e de unhas não são tão fáceis de esconder. Se, ao contrário, a causa da morte fora o ato sexual praticado minutos antes, aí então não haveria riscos de nenhum vestígio físico. Bastaria cobrir o defunto com um lençol até o queixo.

Quando o autor resolve criar situações de iniciativas para a nossa personagem, nós leitores vamo-nos deparando com situações que envolvem a racionalização como mecanismo egóico, sendo essa a única maneira de esquecer ou fugir da culpa. Na verdade, esse é um 
mecanismo que percebemos o tempo todo ao relatar a história e omitir seus verdadeiros desejos sexuais. Neste momento, tudo parece ser explicado com uma razão para que não descubram que ela matou o coronel. Pensa em fugir, mas em seguida alerta para o fato de que isso poderia causar suspeita; não podemos nos esquecer de que a personagem já havia plantado álibis junto ao vigário e ao médico, mesmo que o motivo seja o pretexto real carta que recebera dias antes, dizendo que o irmão não estava bem. Outro exemplo de racionalização aconteceu na preparação do cadáver. O enfermeiro chama para ajudá-lo um velho empregado preto e míope. Ainda relata não ter saído de perto do cadáver, com medo de que descobrissem algo. O que ele poderia estar querendo ocultar, em sua culpa?

Evidências de sua ansiedade fazem com que sinta a necessidade de fazer uma leitura não verbal sobre as expressões das pessoas que entrassem na sala mortuária. Aqui percebemos claramente que racionaliza mais uma vez, agora quanto à questão do olhar, denotando também os seus poderes alucinatórios. Somente com o olhar, poderia descobrir tudo sobre o que as pessoas estariam pensando ao entrar ali. Sendo assim, encontrou uma maneira para se defender de qualquer possível acusação, deixando de olhar diretamente no olhar dos outros, pois isso poderia denunciá-lo como assassino, ou então somente com o olhar ela poderia desviar a atenção de quem entrasse para "reparar" o defunto. A ansiedade também se faz presente ao relatar a impaciência do cortejo ao defunto, com as visitas que ali chegavam e com as orações.

Essa mesma ansiedade atinge a nós leitores, fazendo-nos questionar se ninguém perceberia o que ocorrera de fato. Caímos na intenção do autor e no seu interjogo psíquico, que explora de maneira graciosa os impulsos do Id em contraposição ao Ego. Nesse momento o autor consegue fazer com que nos sintamos cúmplices dele e, ao mesmo tempo, do enfermeiro.

O autor cria um suspense ao relatar que, ao fechar o caixão, evidencia tal ansiedade nas mãos trêmulas. Aí então pensamos que é chegada a hora da descoberta da verdade. Mas outra vez o autor 


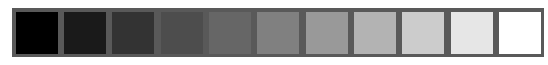

Xavier, I. A. O interjogo consciente-inconsciente

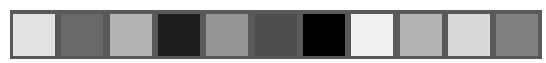

nos coloca confusos, ao inserir uma pessoa na história, que percebe as mãos trêmulas da personagem, mas interpreta o fato como expressão de pesar, mesmo tendo sofrido tanto nas mãos do coronel. Poderíamos supor que essa pessoa percebe a evidência de um vínculo afetivo entre os dois e faz questão de dizer o que percebe, caso contrário não estranharia o pesar nessas condições.

Isso soa como ironia aos seus olhos, pois entende perfeitamente a intenção da pessoa que se atreve a expô-lo nesse momento. Para nós parece uma cegueira coletiva, pois até então ninguém se dá conta da realidade. Estaríamos nós indignados com a situação ou torcendo pela personagem?

Esse suspense infernal nos atormenta até o momento em que, passada a noite do terrível crime e saindo da meia escuridão da casa, em que todo tipo de visão parecia se dar de forma nebulosa ou distorcida, relata que consegue superar a claridade e enfrentar as pessoas que observam, apenas com o gesto de olhar para o chão, sentindo-se em paz depois de tudo acabado. Com o fato consumado, ou seja, a morte do coronel, sentir-se exposta ou falada pela cidade já não fazia tanta diferença.

Quando pensamos que estaria tudo resolvido, ou seja, de um lado ela estaria livre do velho tirano e do outro a cidade também, começa a relatar o quanto Ihe foram difíceis às primeiras noites, sendo acometida de insônias, pesadelos, falta de apetite, falta de alegria, enfim, falta do coronel dormindo ao seu lado. Neste momento o autor nos faz pensar em duas hipóteses, ou estava sentindo-se culpada ou com saudades daquela relação neurótica. O autor cria uma situação nebulosa para nós e para os que circundam o enfermeiro, que interpretam que este está melancólico com o ocorrido. Há sem dúvida, uma percepção geral do estado de viuvez em que se encontra. A própria personagem nos relata que tirava proveito da ilusão das pessoas para também poder elogiar o coronel, dizendo até mesmo que o coronel tinha um coração de ouro.

Sendo ou não mais um interjogo psíquico, relata a necessidade de se convencer da bondade do coronel (através da ilusão do outro) ou aproveitar desta ilusão, para poder expressar seus verdadeiros 


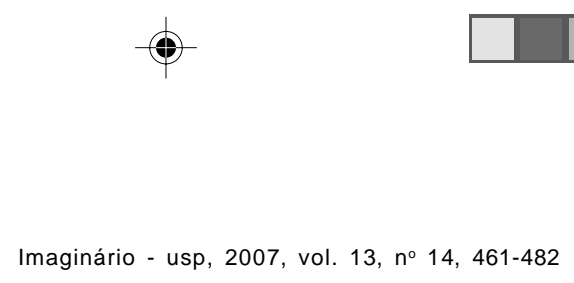

sentimentos em relação ao coronel, mesmo sendo por alguns minutos. Neste momento, perguntamo-nos: se tudo o que ela conta é verdade, onde está o lcs? Suportando ou não esta realidade que a cerca, e sem meios de controle das instâncias, ela resolve sair deste contexto social culpabilizante, talvez para se proteger e se fortalecer psiquicamente.

Outra revelação interessante que nos faz é a respeito de sua crença. Diz que, mesmo não sendo religiosa, manda rezar uma missa para o coronel. Aqui nós sentimos a sua preocupação em se redimir de sua culpa, coisa que prefere fazer sem testemunhas. Porém, parece não precisar de Deus, nem de um padre para se confessar; acredita que só ela pode se autoperdoar e passa o tempo todo de joelhos, fazendo o sinal da cruz repetidamente. Por último, considera importante acrescentar que sempre se refere ao coronel dizendo: "Deus Ihe fale n'alma" como se estivesse muito próximo de Deus e desse-Ihe ordem para apontar a culpa do defunto.

Como uma concretização de sua inocência, relata em seguida que através de uma carta do vigário (no seu oitavo dia na Corte) ficou sabendo da notícia de que era a única herdeira do coronel. Perguntamo-nos se uma pessoa que vive intimamente com outra não sabe também de seus segredos e intenções, além do que o coronel estava prestes a morrer. O pretexto de ter ido ao Rio para esperar a carta parece ter sido mais uma de suas artimanhas. Essa era a premiação ou a constatação de que precisava para se sentir publicamente possuidor dos bens do coronel. O número oito parece vir acompanhando de sua vida como mais um pensamento mágico, talvez como o número da revelação de algo importante.

Mais uma vez o autor nos mostra o interjogo psíquico apontando aqui uma proibição que ele próprio se impõe, para que não aceitasse nenhum vintém de tal episódio e ao mesmo tempo se faz valer de inúmeras razões para incriminação, caso não aceitasse tal herança. Ironicamente, o autor trata de reparar o mal cometido pela personagem ao colocar sua decisão em relação à herança. Pensando na questão do escrúpulo e tentando resgatar o crime por um ato de virtude, ela decide que receberia a herança e dá-la-ia aos pobres, 


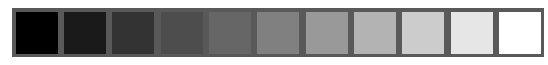

Xavier, I. A. O interjogo consciente-inconsciente

aos poucos e às escondidas. Na verdade, deve decidir se fica ou não com a herança que lhe pertence por direito adquirido, depois de viver intimamente com o coronel. Precisa tomar uma decisão importante de voltar ou não para aquela cidade, onde as pessoas podem estar prontas para julgá-la.

Para nós, fica a idéia de que mais uma vez, guiada pela idéia ilusória, resolve ela mesmo dar à sorte a própria fortuna, tendo em mente a proibição de usá-la, proibição essa que nos parece um tanto quanto duvidosa.

Não tardou e o enfermeiro retorna ao local do crime, o que a faz recordar de seu "triste sucesso", talvez porque perdera seu objeto amado e agora, a única coisa que tinha era a sensação de que a sombra do coronel parecia surgir de cada lado. Deparamo-nos novamente com a possibilidade de contatar com a sua fantasia. Ela, que havia perdido a sua própria identidade em função de um determinado "casamento", como foi dito acima, agora com o seu retorno, tinha a certeza de que o coronel (morto) estaria ao seu lado à vida toda. Todo esse esforço e entrega deveria valer a pena, nem que para isso devesse assumir publicamente a viuvez.

Ao reviver a noite horrenda e aos poucos toda a relação que tivera com o coronel apodera-se de sua mente a idéia fixa de que não houvera crime nenhum e sim uma reação em legítima defesa. Recorda do homem mau que Ihe dirigia injúrias, mas tenta justificar esta maldade, culpando a doença que o tornava assim rabugento. Portanto, para poder aliviar sua culpa, trata de perdoar o coronel. Aqui aparece "fixação", uma defesa que faz com que se convença de que o ocorrido naquela noite fora apenas coincidência, já que o coronel estaria predestinado à morte, mais cedo ou mais tarde, eximindo-a de qualquer culpa.

Por alguns instantes, durante o conto, seu ego tentou se manifestar. Primeiro, quando matou e quis fugir, depois quando saindo para o enterro, expressa a necessidade de querer entregar-se e dizer a verdade e agora retornando para buscar a herança, ao pensar em recuar. Mas o enfermeiro decide o contrário. Dessa última vez, é a cidade inteira que reforça sua atitude, ao parabenizá-lo (a começar 


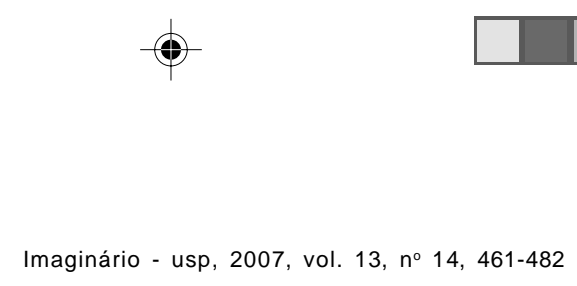

pelo vigário). Coberto de elogios, o enfermeiro virou herói, logo tratou de constituir advogado e ainda defendia o coronel, apontando suas virtudes. Nesse momento, tudo o que o coronel representava e tinha passa a ser de sua propriedade, inclusive sua vida, fortuna e prestígio na cidade. Elogiando o coronel, elogia a si mesmo. Enfrentando a cidade, redime sua culpa.

O que os moradores diziam a respeito do coronel sobre suas perversidades, a princípio, começaram a soar aos ouvidos da personagem como curiosidade, e, em seguida, ela mesma relata que seu coração sentia prazer com as histórias, necessitando expelir esse prazer que retornava por meio de defesas e elogios. Quanto mais injúria ouvia, mais prazer sentia, e até o lugarejo que lhe parecia tenebroso, depois da morte do coronel, foi ficando prazeroso. Percebemos aqui um mecanismo de deslocamento acentuando o funcionamento psíquico, ou seja, quanto mais injúria ouvia, mais prazer sentia, inicialmente vivido com o coronel e agora dirigido aos moradores da cidade.

Diante da fortuna do coronel, confessa que a idéia de transformála em donativo para os pobres desaparecera por completo. Aqui, evidencia-se o poder do dinheiro em sua vida, naquele momento. Podemos dizer que esse poder, até então, parecia não ter se evidenciado. Quanto mais dinheiro mais onipotente e mais fortalecido em suas fantasias. Apropriando-se também do dinheiro, ele resolve doar pouco mais que trinta contos e prestar homenagem ao coronel levantando-lhe um túmulo em mármore.

Até o último instante, o enfermeiro tenta nos convencer de que, por suas mãos ou não, o coronel morreria mais cedo ou mais tarde buscando aliviar sua culpa e o merecimento de perdão. Não bastasse querer nosso perdão, tenta usar de seu poder de sedução com a pessoa para quem vai vender sua história travando um pacto. Um pacto de morte, como aquele que vivenciou com o coronel, ao pedir para si um belo túmulo de mármore.

Denotando sua onipotência final, ousa criar o seu divino sermão da montanha ao pedir que seja escrito em seu epitáfio: "Bem aventurados os que possuem porque eles serão consolados". Assim, sela 


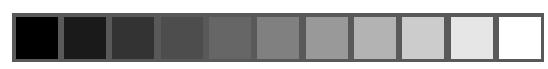

Xavier, I. A. O interjogo consciente-inconsciente

seu final. Um final feliz, em que ter ultrapassado as barreiras psíqui-cas, entregando-se ao interjogo, tornou-a forte, poderosa e, porque não dizer, eterna.

Como conclusão da análise do interjogo consciente e inconsciente no conto "O Enfermeiro" de Machado de Assis, podemos dizer, corroborando Herrman (1993) que é possível transformar método psicanalítico em pesquisa, principalmente em se tratando de obra do mais criativo autor brasileiro, Machado de Assis.

Acreditamos que o intento de Freud (1907) ao analisar a obra de Wilhelm Jensen, somado ao nosso intento de análise da obra de Machado de Assis, depois de quase 100 anos, contribui para incentivar outros autores que queiram, no futuro, ousar de tal análise em outros determinantes de relações sociais, em busca de um "inconsciente relativo" sob a luz psicanalítica.

Resumo: Este estudo teve como principal objetivo investigar o inconsciente em uma obra literária de Machado de Assis, utilizando o conceito de "inconsciente relativo" de Fábio Herrmann. Por meio da obra de arte, o autor entra em relação com o leitor estabelecendo um campo interpsíquico, em que certos aspectos são manipulados por ele determinando as características do campo e direcionando a leitura para determinado objetivo artístico. Os dados foram obti-dos da obra literária de Machado de Assis, O Enfermeiro. A relação interpsíquica entre autor e leitor pode ser investigada, transferencialmente, convertendo método psicanalítico em pesquisa. Outros trabalhos podem corroborar este estudo.

Palavras-chave: inconsciente, Machado de Assis, Psicanálise. 


\begin{abstract}
This study had as its main purpose to investigate the unconsciousness in a Machado de Assis' literary work, using the concept of "relative unconsciousness" by Fabio Hermann's. Through the work of art, the author interacts with the reader establishing an interpsychic field, where some aspects are manipulated by him determining the field's characteristics and directing the reading to a certain artistic purpose. The data were taken from Machado de Assis' literary work - The Nurse. The interpsychic relationship between author and reader can be investigated, transferentially, converting the psychoanalytic method into a research. Others papers can corroborate this study.
\end{abstract}

Key words: unconsciousness, Machado de Assis, Psychoanalysis.

Resumen: Este estudio tuvo como principal objetivo investigar el inconsciente en una obra literaria de Machado de Assis, utilizando el concepto de "inconsciente relativo" de Fábio Herrmann. Por medio de la obra de arte, el autor entra en relación con el lector estableciendo un campo interpsíquico, en que ciertos aspectos son manipulados determinando las características del campo y dirigiendo la lectura para determinado objetivo artístico. Los datos fueron recogidos de la obra literaria de Machado de Assis, O Enfermeiro. La relación inter-psíquica entre autor y lector puede ser investigada, transferencialmente, convirtiendo el método psicoanalítico en pesquisa. Otros trabajos pueden corroborar este estudio.

Palabras clave: inconsciente, Machado de Assis, Psi-coanálisis. 
ASSIS, M. (1839 - 1908) O Enfermeiro. In: Contos Consagrados. Biografia por M. Cavalcanti Proença; Introdução de Ivan Proença. R.J.: Ediouro; São Paulo: Publifolha (1997) Biblioteca Folha, 25. p. 93101.

FREUD, S. Delírios e Sonhos na Gradiva de Jensen. Edição Standart Brasileira das Obras Psicológicas Completas de Sigmund Freud. RJ: Imago. p. 17-98, 1907.

O EGO e o ID. Edição Standart Brasileira das Obras Psicológicas Completas de Sigmund Freud. RJ, Imago. 19, p. 23 54, 1923.

HERRMANN, F. Uma aventura: A tese psicanalítica (Entrevista com Fábio Herrmann). In: Investigação e psicanálise. Coord. Silva, M.E.L. SP: Papirus. p. 133-158, 1993.

. Andaimes do Real II: o cotidiano, São Paulo, Vértice, 1985.

REZENDE, A. M. Psicanálise e filosofia das ciências: a questão da verdade. IDE Sociedade Brasileira de Psicanálise de S.P. $\mathrm{n}^{\circ} 14 . \mathrm{p}$. 21-24, 1987.

e-mails: iaxavier@uol.com.br; iaxavier@unip.br Recebido em 18/08/2006.

Aceito em 10/09/2006. 